\title{
Character Association and Path Analysis for Quantitative Traits in Advanced Breeding Lines of Sesame (Sesamum indicum L.)
}

\author{
Hukumchand and S. G. Parameshwarappa* \\ Department of Genetics and Plant Breeding, College of Agriculture University of Agricultural \\ Sciences, Dharwad - 580 005, Karnataka, India \\ *Corresponding author
}

\section{Keywords}

Association, Path analysis, Sesame

Article Info

Accepted:

25 November 2019

Available Online:

10 December 2019
Association and path coefficient analysis was computed on 96 genotypes of Sesamum (Sesamum indicum L.). Seed yield was positively correlated with plant height, number of branches per plant, number of capsules per plant, capsule length and 1000 seed weight. Selection based onplant height, number of branches per plant, number of capsules per plant and capsule length would increase seed yield. Path analysis indicated that number of capsules per plant had the maximum direct effect followed by plant height, capsule length and height to first capsule.

\section{Introduction}

The word sesame derived from Latin word 'sesamum' and Greek word 'sesamon' which means seed or fruit of sesame plant. Sesame (Sesamum indicum. L), also known as 'ellu' in 'Kannada', 'til' in Hindi and 'nuvvulu' in Telugu, is an ancient crop known to mankind. It is an indigenous crop of India after groundnut and brassica oilseeds. Weiss (1883) and several other were having view that it was originated in south western Africa. In Africa most of the cultivated and wild species of sesame occurs. It might have introduced through countries like Indonesia and Malaysia before Aryan dynasty. Sesamum indicum. L, is one among total 13 genera. It belongs to the family Pedaliaceae and order Tubiflorae. There are 36 species including the cultivated species (Sesamum indicum L.) which has chromosome number $2 \mathrm{n}=26$.

The level of variability and the magnitude of diversity for useful traits present in the material is important for development of improved varieties/hybrids. Genetic variability is more important to a breeder to develop improved material and for successful hybridization programme. Always yield is a complex character which is controlled by numerous genes (polygenic), which is affected by environment by a greater extent. So 
emphasis should be given to traits which are less affected by environment. Apart from splitting of total variance into phenotypic and genotypic, it's also essential to be aware of the level of correlation between various traits affecting the yield component. In order to partition correlation coefficients using path coefficient analysis, which helps to every component part affecting yield. Path coefficient analysis measures the direct influence of a variable upon yield and permits the partitioning of the correlation coefficient into components of direct and indirect effects. The present study was therefore conducted to investigate the nature of correlations by path analysis for seed yield.

\section{Materials and Methods}

Ninety six advanced breeding lines along with checks (JTS-8, TKG-22, GT-10 and DS-5) were evaluated at Main Agricultural Research Station, University of Agricultural Sciences, Dharwad (Karnataka) during kharif, 2018 in a Randomized Complete Block Design with two replications. Each genotype was sown in a single row of $3 \mathrm{~m}$ length at a distance of 30 $\mathrm{cm}$ between the rows and $15 \mathrm{~cm}$ between the plants within the rows. Five plants in each row were selected at random and the data on ten characters viz., days to 50 per cent flowering, days to maturity, plant height $(\mathrm{cm})$, plant height to first capsule $(\mathrm{cm})$, number of branches per plant, number of capsules per plant, capsule length $(\mathrm{cm}), 1000$ seed weight (g), oil content (\%) and seed yield per plant (g) were analyzed and correlations were computed. The pathco-efficient analysis at genotypic level was computed by Deway and Lu (1959) procedure.

\section{Results and Discussion}

At both phenotypic and genotypic level, traits such as plant height, number of capsules, number of branches, height to first capsule, capsule length, oil content and 1000 seed weight had positive significant association with seed yield per plant (Table. 1 and 2).The character plant height has showed significant positive correlation with seed yield/plant both at genotypic as well as at phenotypic level concluding that plant height is a dependable measure of yield and choosing the tall lines would be productive (Fig. 1). These results are in accordance with Sudhakar et al., (2007), Sumathi et al., (2007), Yingzhong and Yishou (2002), Engin Yol et al., (2010), Ibrahim and Khidir (2012), Ammara Fazal et al., (2015), Yirga (2017) and Atul Singh et al., (2018).

The trait capsules per plant had highly significant positive association with seed yield per plant both at genotypic and phenotypic level designating that this trait is dependable criteria for choosing of higher yielding lines. The results are in accordance with Sudhakar $e t$ al., (2007), Sumathi et al., (2007), Engine Yol et al., (2010). One of the study by Ammara Fazal et al., (2015) has indicated that there is an increase in yield if we select high capsule bearing line. Significant positive association observed between capsule length with seed yield per plant both at genotypic as well as at phenotypic level is a dependable measure while selecting high yielding lines, the outcomes are in consonance with Sudhakar et al., (2007), Parameshwarappa et al., (2009) and Baoreima et al., (2016).

There was positive significant association between height to first capsule and seed yield pert plant. The results are in consonance with Ibrahim and Khidir (2012). Generally, less height to first capsule will be preferred since plant has less height to first capsule then more number of capsules can be formed at above plant part which leads to increase in yield level. The trait 1000 seed weight had positive significant association with seed yield/plant both at phenotypic and genotypic level. The line which is having higher seed weight will 
be helping in improving seed yield/plant. The outcomes are in consonance with Ammara Fazal et al., (2015) and Vina et al., (2017).

There was positive significant correlation between branches per plant and seed yield/plant, more number of branches leads to more capsules per plant ultimately helps in improving yield/plant these results are in consonance with Vina et al., (2017) and Yirga (2017). There was positive non-significant correlation between oil content and seed yield/plant the outcome were in consonance with Sumathi et al., (2007) and Khairnar and Monpara (2013). There was negative nonsignificant correlation between days to $50 \%$ flowering and days to maturity with seed yield/plant. The results are in consonance with Akbar et al., (2011), Khairnar and Monpara (2013), Baraki et al., (2015). On the other hand, Hika et al., (2014), observed that there was significant positive correlation. Therefore, selecting tall plants with more number of capsules, longer capsule length, high number of branches and high 1000 seed weight will lead to increase in yield. In order to understand ideal plant type, it is also important to know significant inter-relationship between the traits. The information regarding the correlation among the yield contributing characters and magnitude of interrelationship with each other helpful in improvement of more than one character along with seed yield/plant.

The trait, days to $50 \%$ flowering exhibited positive and significant association with days to maturity and height to first capsule, these outcomes in accordance with results of Sudhakar et al., (2007), Parameshwarappa et al., (2009), Sumathi and Muralidharan (2010), Ibrahim and Khidir (2012), Ammara Fazal et al., (2015) and Barakiet al., (2016) for days to maturity. Ibrahim and Khidir (2012) and Engin Yol et al., (2010) for capsules per plant and for capsule length Sudhakar et al., (2007).
The character days to maturity has positive significant correlation with days to $50 \%$ flowering and height to first capsule, the results are in accordance with Engin Yol et al., (2010).

There was positive significant association between plant height and the traits such as height to first capsule, branches per plant, capsules/plant and oil content. This results are in consonance with results of Goudappagoudra et al., (2011), Ibrahim and Khidir (2012) and Ammara Fazal et al., (2015) for height to first capsule. Sudhakar (2007), Sumathi et al., (2007), Parameshwarappa et al., (2009a) and Engin Yol et al., (2010) for the trait capsule/plant. Sudhakar et al., (2007) and Parameshwarappa et al., (2009a) for the trait capsule length and Engin Yolet al., (2010) and Ammara Fazal et al., (2015) for number of branches per plant and Atul Singh et al., (2018) for oil content. There was a positive significant correlation between number of branches and traits like plant height, height to first capsule, number of capsules, 1000 seed weight and oil content the results are in consonance with Yirga (2017) and Atul Singh et al., (2018).

There was highly significant positive correlation of number of capsules with traits such as plant height, height to first capsule, branches/plant, capsule length and 1000 seed weight, these results are in accordance with Solanki and Gupta (2003), for plant height, branches and number of capsules. Motilal and Manoharan (2006) for seeds per capsule and 1000 seed weight. Sumathi et al., (2007) for all traits except 1000 seed weight. Atul Singh et al., (2018) for oil content and plant height.

Capsule length had showed positive significant correlation with thousand seed weight and oil content, these results are in consonance with Sudhakar et al., (2007), Vina et al., (2017) and Atul Singh et al., (2018). 
Table.1 Genotypic correlation coefficients between seed yield and component traits in sesame

\begin{tabular}{|c|c|c|c|c|c|c|c|c|c|c|c|}
\hline $\begin{array}{c}\text { Sl. } \\
\text { No. }\end{array}$ & Characters & X1 & $\mathrm{X} 2$ & X3 & X4 & X5 & X6 & X7 & X8 & X9 & X10 \\
\hline 1 & X1 & 1.000 & $0.873 * *$ & 0.016 & $0.259 * *$ & -0.049 & -0.014 & -0.114 & -0.013 & -0.111 & -0.076 \\
\hline 2 & $\mathbf{X} 2$ & & 1.000 & 0.026 & $0.251 * *$ & -0.051 & -0.013 & -0.076 & -0.011 & -0.012 & -0.067 \\
\hline 3 & $\mathbf{X 3}$ & & & 1.000 & $0.542 * *$ & $0.817 * *$ & $0.571 * *$ & 0.005 & $0.458 * *$ & -0.010 & $-0.170 *$ \\
\hline 4 & $\mathrm{X} 4$ & & & & 1.000 & $0.544 * *$ & $0.189 * *$ & $0.258 * *$ & 0.141 & $-0.246 * *$ & $0.301^{* *}$ \\
\hline 5 & X5 & & & & & 1.000 & $0.651 * *$ & 0.035 & $0.329 * *$ & $0.165 *$ & $0.230 * *$ \\
\hline 6 & X6 & & & & & & 1.000 & $0.292 * *$ & $0.678 * *$ & $0.182 *$ & 0.032 \\
\hline 7 & $\mathbf{X} 7$ & & & & & & & 1.000 & $0.363 * *$ & $0.514 * *$ & $0.163 *$ \\
\hline 8 & X8 & & & & & & & & 1.000 & $0.279 * *$ & 0.107 \\
\hline 9 & X9 & & & & & & & & & 1.000 & $0.463 * *$ \\
\hline 10 & X10 & & & & & & & & & & 1.000 \\
\hline
\end{tabular}

$\mathrm{X} 1$. Days to $50 \%$ flowering

$\mathrm{X} 2$. Days to maturity

X3. Plant height $(\mathrm{cm})$

X4. Height to first capsule $(\mathrm{cm})$

$\mathrm{X}$. Number of branches per plant

X6. Number of capsules per plant

X7. Capsule length $(\mathrm{cm})$

$\mathrm{X} 8$. Seed yield per plant $(\mathrm{g})$

$\mathrm{X} 9.1000$ seed weight $(\mathrm{g})$

X10. Oil content (\%) 
Table.2 Phenotypic correlation coefficients between seed yield and component traits in sesame

\begin{tabular}{|c|c|c|c|c|c|c|c|c|c|c|c|}
\hline SI. No. & Characters & X1 & $\mathrm{X} 2$ & X3 & X4 & X5 & X6 & X7 & X8 & X9 & X10 \\
\hline 1 & X1 & 1.000 & $0.986 * *$ & -0.049 & 0.107 & 0.017 & -0.031 & -0.131 & -0.225 & -0.018 & -0.039 \\
\hline 2 & $\mathbf{X} 2$ & & 1.000 & -0.042 & 0.107 & 0.007 & -0.101 & -0.052 & -0.212 & -0.032 & -0.038 \\
\hline 3 & $\mathbf{X 3}$ & & & 1.000 & $0.499 * *$ & $0.594 * *$ & $0.513 * *$ & $0.163^{*}$ & $0.367 * *$ & -0.036 & -0.057 \\
\hline 4 & $\mathrm{X} 4$ & & & & 1.000 & $0.368 * *$ & $0.187 * *$ & -0.112 & 0.115 & $0.227^{* *}$ & -0.095 \\
\hline 5 & X5 & & & & & 1.000 & $0.526 * *$ & 0.101 & $0.280 * *$ & 0.134 & -0.019 \\
\hline 6 & X6 & & & & & & 1.000 & $0.228 * *$ & $0.661 * *$ & $0.145^{*}$ & -0.044 \\
\hline 7 & $\mathbf{X} 7$ & & & & & & & 1.000 & $0.246^{*}$ & $0.275^{* *} *$ & 0.092 \\
\hline 8 & X8 & & & & & & & & 1.000 & $0.246 * *$ & 0.027 \\
\hline 9 & $\mathbf{X 9}$ & & & & & & & & & 1.000 & $0.161 *$ \\
\hline 10 & X10 & & & & & & & & & & 1.000 \\
\hline
\end{tabular}

**, * - Significant at $1 \%$ and 5\% level of probability

$\mathrm{X} 1$. Days to $50 \%$ flowering

$\mathrm{X} 2$. Days to maturity

X3. Plant height $(\mathrm{cm})$

X4. Height to first capsule $(\mathrm{cm})$

X5. Number of branches per plant

X6. Number of capsules per plant

X7. Capsule length $(\mathrm{cm})$

X8. Seed yield per plant $(\mathrm{g})$

X9. 1000 seed weight $(\mathrm{g})$

X10. Oil content (\%) 
Table.3 Direct (diagonal) and indirect effects of characters on seed yield at genotypic level in sesame

\begin{tabular}{|c|c|c|c|c|c|c|c|c|c|c|c|}
\hline $\begin{array}{c}\text { Sl. } \\
\text { No. }\end{array}$ & Characters & X1 & $\mathrm{X} 2$ & $\mathbf{X 3}$ & $\mathrm{X} 4$ & X5 & X6 & $\mathbf{X 7}$ & X9 & X10 & $\begin{array}{c}\text { Genotypic } \\
\text { correlation } \\
\text { with seed } \\
\text { yield }\end{array}$ \\
\hline 1 & X1 & -0.443 & 0.446 & -0.007 & -0.114 & 0.021 & 0.102 & 0.050 & 0.147 & 0.033 & -0.028 \\
\hline 2 & $\mathbf{X} 2$ & 0.182 & 0.181 & 0.004 & 0.045 & -0.009 & -0.039 & -0.013 & -0.052 & -0.012 & -0.017 \\
\hline 3 & $\mathbf{X 3}$ & 0.008 & 0.014 & 0.548 & 0.297 & 0.448 & 0.013 & 0.003 & -0.005 & -0.093 & $0.458 * *$ \\
\hline 4 & X4 & 0.060 & 0.059 & 0.127 & 0.234 & 0.127 & 0.044 & -0.060 & -0.057 & -0.070 & $0.141^{*}$ \\
\hline 5 & X5 & 0.035 & 0.036 & 0.581 & -0.038 & -0.710 & 0.463 & -0.025 & 0.117 & 0.163 & $0.329 * *$ \\
\hline 6 & X6 & -0.114 & -0.106 & 0.380 & 0.126 & 0.434 & 0.666 & 0.195 & 0.121 & 0.021 & $0.678 * *$ \\
\hline 7 & $\mathbf{X 7}$ & -0.033 & -0.022 & 0.001 & -0.076 & 0.010 & 0.086 & 0.295 & 0.151 & 0.048 & $0.363 * *$ \\
\hline 8 & X9 & 0.063 & 0.055 & 0.002 & 0.046 & 0.0314 & -0.03 & -0.097 & -0.190 & -0.088 & $0.279 * *$ \\
\hline 9 & X10 & -0.008 & -0.007 & -0.017 & -0.031 & 0.024 & 0.003 & 0.017 & 0.048 & 0.104 & 0.107 \\
\hline
\end{tabular}

**, * - Significant at $1 \%$ and $5 \%$ level of probability, respectively

$\mathrm{X} 1$. Days to $50 \%$ flowering

$\mathrm{X} 2$. Days to maturity

X3. Plant height $(\mathrm{cm})$

$\mathrm{X} 4$. Height to first capsule $(\mathrm{cm})$

X5. Number of branches per plant

X6. Number of capsules per plant

X7. Capsule length $(\mathrm{cm})$

X9. 1000 seed weight $(\mathrm{g})$

X10. Oil content (\%) 
Fig.1 Genotypic path diagram for seed yield and component characters under study

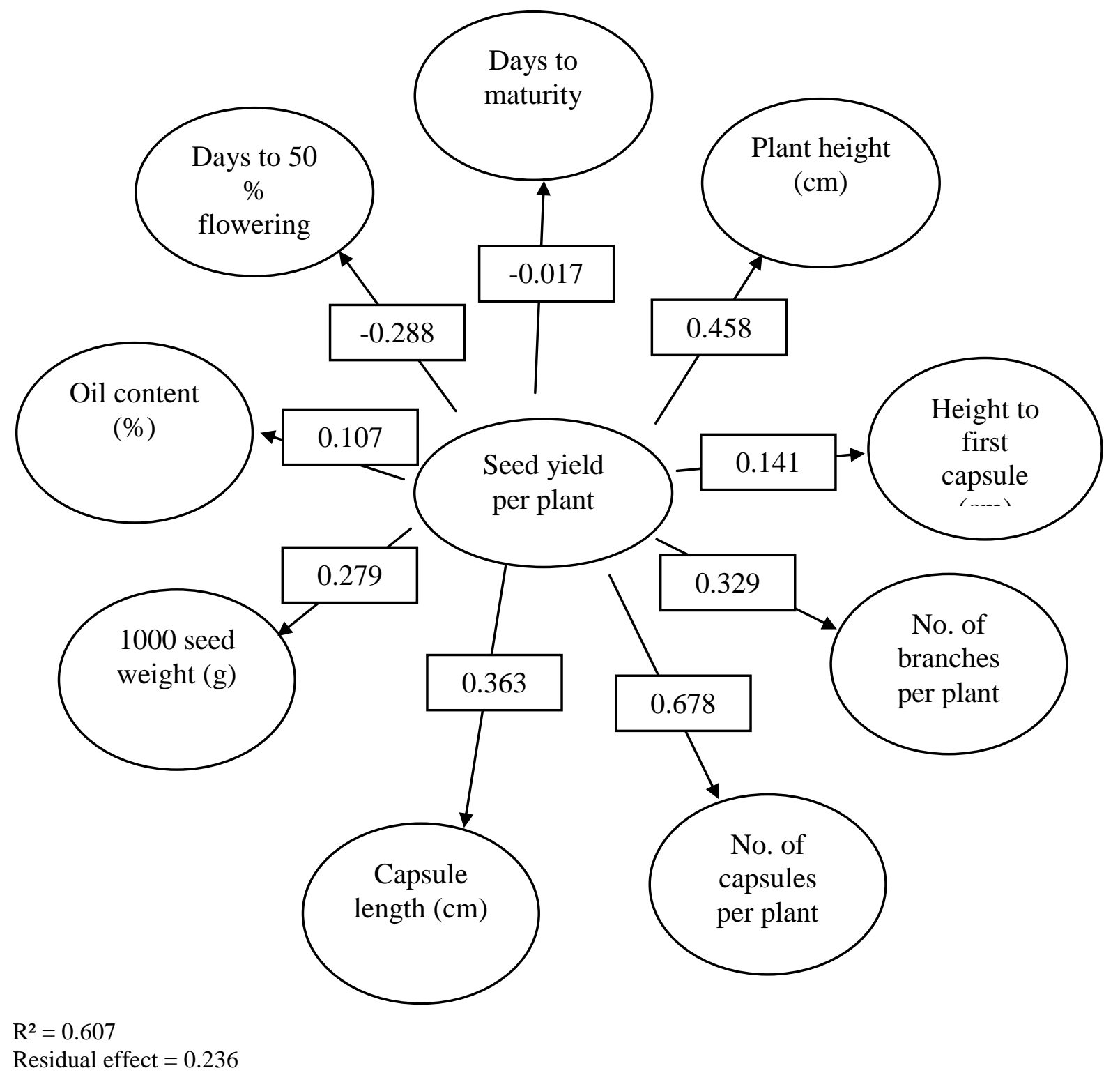


Int.J.Curr.Microbiol.App.Sci (2019) 8(12): 2980-2990

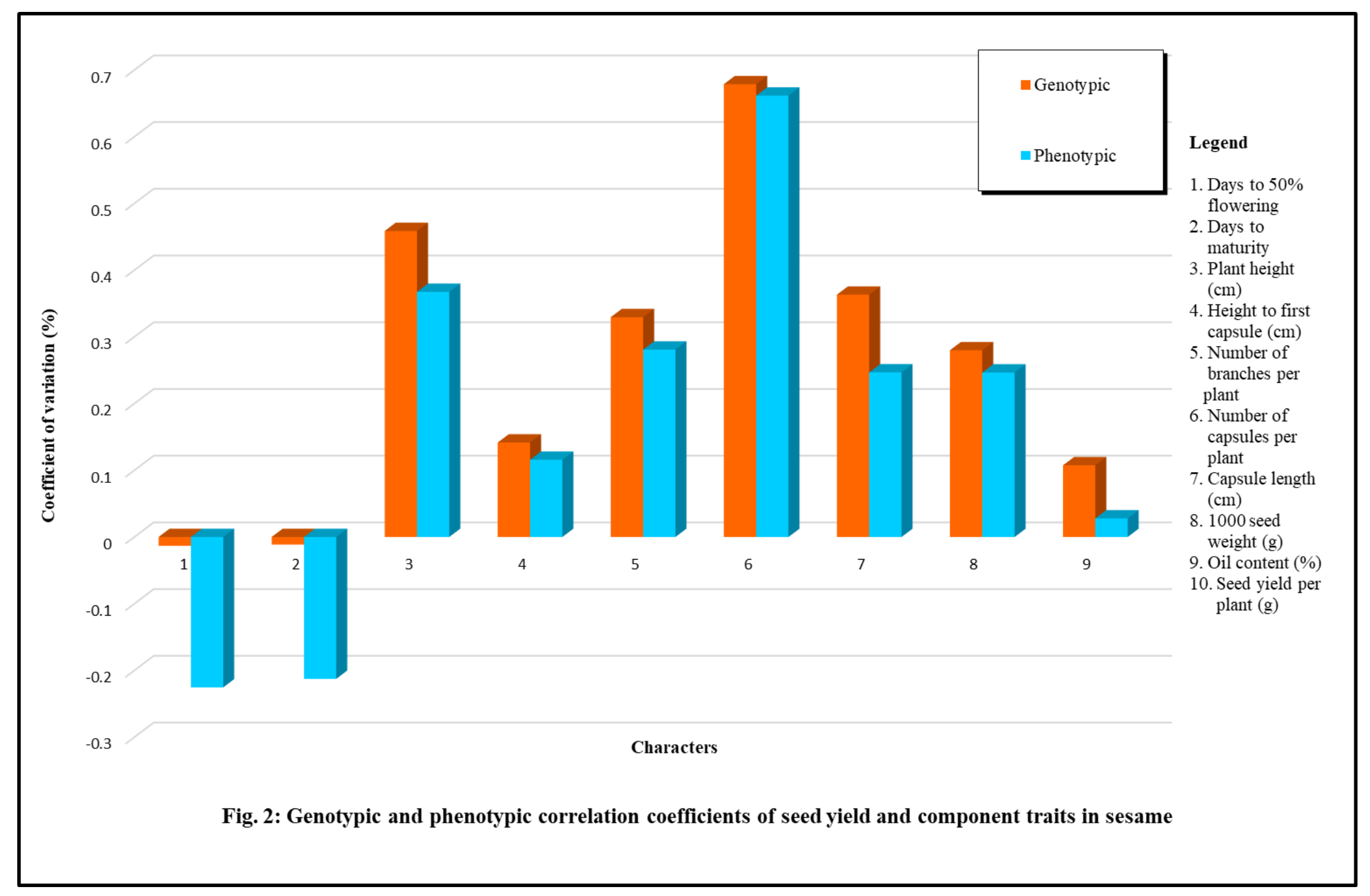


However, in the present study the trait seed yield per plant had significantly associated with number of capsule, plant height, number of branches and also capsule length, so while practising selection those correlations have to be kept in mind. Correlation study helps us to know only the nature of association between the character and yield attributes, it does not depict direct and indirect effect. Therefore, by using path analysis, we can assess the direct and indirect effects.

In the current investigation path analysis computed at genotypic level (Table. 3). Among all the traits highest direct effect was shown by number of capsules/plant on seed yield, the results are in accordance with Sumathi et al., (2007) and Ashok Shindhe (2009). If there are more number capsules per plant that will lead to increase in seed yield per plant. Plant height has negative direct effect on seed yield per plant it was also reported by Ammara Fazal et al., (2015). Nevertheless, plant height had significant quantity of indirect effect through capsules per plant. So when direct selection for plant height will improve capsules/plant ultimately it improves seed yield per plant indirectly (Fig. 2).

Height to first capsule was having positive direct effect on seed yield per plant and had high indirect effect via number of branches per plant, the results are in consonance with Biabani and Pakniyat (2008), Ashok Shindhe (2009) and Allolli (2009). Branches/plant had negative direct effect and its indirect effect was positive through plant height was higher, the results are in agreement with Engin Yol et al., (2010). There was positive direct effect between character capsule length on seed yield per plant and indirect effect was higher through 1000 seed weight, the results are in accordance with Sudhakar et al., (2007). 1000 seed weight has negative direct effect on seed yield per plant, the outcomes are in consonance with Hika et al., (2014). On the other side positive direct effect of 1000 seed weight with seed yield/plant was reported by Ibrahim and Khidir (2012). Most of the traits showed positive indirect effect on seed yield per plant but some of the traits such as capsule length in accordance with Biabani and Pakniyat (2008) and oil content showed negative indirect effect on seed yield per plant, this is in agreement with Siddique et al., (2005).

From the present investigation it is found that capsule/plant, plant height, capsule length and plant height to first capsule was to given more importance during the selection because these characters showing high direct effect and higher correlation with character seed yield per plant and it has direct contribution towards yield per plant by number of capsules, hence these traits must be kept in mind while practising selection for improvement of seed yield.

\section{References}

Akbar, F., Rabbani, M. A., Shinwari, Z. K. and Khan, S. J., 2011, Genetic divergence in sesame (Sesamum indicum L.) landraces based on qualitative and quantitative traits. Pak. J. Bot., 43(6): 2737-2744.

Allolli, M. R., 2009, Genetic variability studies for male sterility segregating generation of inter-specific cross of sesame (Sesamum indium L.). Karnataka J. Agric. Sci., 22(5): 11541205.

Ammara Fazal, Hafiz Saad Bin Mustafa, Ejazul-Hasan, Muhammad Anwar, Muhammad HammadNadeemTahir and Hafeez Ahmad Sadaqat, 2015, Interrelationship and path coefficient analysis among yield and yield related traits in sesame (Sesamum indicum L.). Nat. Sci., 13(5) : 45-51. 
Ashok Shindhe, 2009, Phenotypic and molecular characterization of mutants of $\mathrm{M}_{3}$ generation for selected characters in sesame (Sesamum indium L.). M. Sc. (Agri) Thesis, Univ. Agric. Sci., Dharwad (India).

Atul Singh., B, Rajani and Akanksha, T., 2018, Genetic variability and character association in sesame (Sesamum indicum L.) genotypes, Int. J. Curr. Microbiol. App. Sci., 7(11): 2407-2415

Baraki. F., Tsehaye, Y. and Abay, F., 2015, Grain yield based cluster analysis and correlation of agronomic traits of sesame (Sesamum indicum L.) genotypes in Ethiopia. J. Natural. Sci. Res., 5(9): 11-17.

Biabani, A. R. and Pakniyat, H., 2008, Evaluation of seed yeild-related characters in sesame (Sesamum indium L.) using factor and path analysis. Pak. J. Biol. Sci., 11(8): 1157-1160.

Boureima, S., Diouf, M., Amoukou, A. I. and Van, D. P., 2016, Screening for sources of tolerance to drought in sesame induced mutants assessment of indirect selection criteria for seed yield. Int. J. Pure App. Biosci., 4 (1): 45-60.

Dewey, D. H. and Lu, K. H., 1959, A correlation and path coefficient analysis of components of crested wheat grass seed production. Agron. J., 51: 515-518.

Goudappagoudra, R., Lokesha, R. and Ranganatha, A. R. G., 2011, Trait association and path coefficient analysis for yield and yield attributing traits in sesame (Sesamum indicum L.). Ele. J. Pl. Breed., 2(3): 448-452.

Hika, G., Geleta, N. and Jaleta, Z., 2014, Correlation and divergence analysis for phenotypic traits in sesame (Sesamum indicum L.) genotypes. Sci. Technol. Arts Res. J., 3(4): 01-09.

Ibrahim, S. E. and Khidir, M. O., 2012,
Genotypic correlation and path coefficient analysis of yield and some yield components in sesame (Sesamum indium L.). Int. J. Agri. Sci., 2(8):664670.

Khairnar, S. S. and Monpara, B. A., 2013, Identification of potential traits and selection criteria for yield improvement in sesame (Sesamum indicum L.) genotypes under rainfed conditions. Iranian J. Genet. $\mathrm{Pl}$. Breed., 2(2): 1-8.

Mothilal, A. A. and Manoharan, N., 2006, Character association and path analysis for yield and yield components in sesame (Sesamum indicum L.). Res. on Crops, 7 : 238-240.

Parameshwarappa, S. G, Palakshappa, M. G, Salimath and K. G. Parameshwarappa, 2009a, Studies on genetic variability and character association in germplasm collection of sesame (Sesamum indicum L.). Karnataka J. Agric. Sci., 22 (2) : 252-254.

Siddiqui, M. A., Baig, K. S. and Patil, P. V., 2005, Correlation and path analysis studies for yield and yield contributing characters in sesame (Sesamum indium L.). J. Res., ANGRAU, 33(1): 31-35.

Solanki, Z. S. and Gupta, S., 2003, Variability and character association among quantitative characters of sesame. $J$. Oilseeds Res., 20(2): 276-277.

Sudhakar, N., Sridevi, O. and Salimath, P. M., 2007, Variability and character association analysis in sesame (Sesamum indium L.). J. Oilseeds Res., 24(1): 56-58.

Sumathi, P. and Muralidharan, V., 2010, Analysis of genetic variability, association and path analysis in the hybrids of sesame (Sesamum indium L.). Tropical Agric. Res. Extn., 13(3): 63-67.

Sumathi, P., Muralidharan, V. and Manivannan, N., 2007, Trait 
association and path coefficient analysis for yield and yield attributing traits in sesame (Sesamum indium L.). Madras Agric. J., 94(7-12): 174-178.

Vina, E. A., and Rani, A. W., 2017, Genetic variability, standardized multiple linear regression and principal component analysis to determine some important sesame yield components. AGRIVITA J. Agric. Sci., 39(1): 83-90.

Weiss, E. A., 1883, Oilseed Crops, Longman, London, pp. 280-294.

Yingzhong, Z. and Yishou, W., 2002, Genotypic correlations and path coefficient analysis in sesame. Sesame and Safflower Newsltr., 17: 10-12.

Yirga, B. K., 2017, Correlation and cluster analysis of white seeded sesame (Sesamum indicum L.) genotypes oil yield in northern Ethiopia. Afr. $J$. Agric. Res., 12(12): 970-978.

Yol, E., Karaman, E., Furat, S. and Uzun, B., 2010, Assessment of selection criteria in sesame by using correlation coefficients, path and factor analyses. Australian. J. Crop Sci., 4(8): 598-602.

\section{How to cite this article:}

Hukumchand and Parameshwarappa, S. G. 2019. Character Association and Path Analysis for Quantitative Traits in Advanced Breeding Lines of Sesame (Sesamum indicum L.). Int.J.Curr.Microbiol.App.Sci. 8(12): 2980-2990. doi: https://doi.org/10.20546/ijcmas.2019.812.346 